\title{
Influence of Atmospheric Oxygen Concentration on Acetylene Reduction and Efficiency of Nitrogen Fixation in Intact Klebsiella pneumoniae
}

\author{
By SUSAN HILL \\ Agricultural Research Council, Unit of Nitrogen Fixation, \\ University of Sussex, Falmer, Brighton BNx $9 Q J$
}

(Received 6 August 1975)

\begin{abstract}
SUMMARY
Oxygen-limited ( $\mathrm{N}_{2}$-fixing) chemostat cultures of Klebsiella pneumoniae supplied with a $\mathrm{N}$-free medium were established by introducing low atmospheric $\mathrm{O}_{2}$ concentrations into the gas supply of anaerobic glucose-limited $\mathrm{N}_{2}$-fixing chemostat cultures; the molar growth yield for glucose and the efficiency of $\mathrm{N}_{2}$ fixation ( $\mu \mathrm{g} \mathrm{N}$ fixed $/ \mathrm{mg}$ glucose consumed) were increased (by up to $82 \%$ ) from the anaerobic values.

Acetylene-reducing activity was inhibited reversibly by $\mathrm{O}_{2}$ in samples from $\mathrm{O}_{2}$-limited and anaerobic glucose-limited chemostat cultures. Oxygen uptake rates in samples from these chemostat cultures were similar, but $\mathrm{C}_{2} \mathrm{H}_{2}$-reducing activity in samples from $\mathrm{O}_{2}$-limited chemostat cultures was more tolerant of low atmospheric $\mathrm{O}_{2}$ concentrations, in part because of a higher population density. In the absence of glucose, $\mathrm{O}_{2}$ was required at a low atmospheric concentration for $\mathrm{C}_{2} \mathrm{H}_{2}$ reduction in samples from either $\mathrm{O}_{2}$-limited or anaerobic glucose-limited chemostat cultures. The possibility is discussed that ATP generated from oxidative phosphorylation can be used for $\mathrm{N}_{2}$ fixation in $K$. pneumoniae.
\end{abstract}

\section{INTRODUCTION}

Nitrogenase, the enzyme responsible for biological $\mathrm{N}_{2}$ fixation from all sources examined so far, consists of two $\mathrm{O}_{2}$-sensitive proteins (see Eady \& Postgate, 1974). However, nitrogenase in crude extracts prepared by decompression of an organism, is often less $\mathrm{O}_{2^{-}}$ sensitive than the component proteins, and shows some organism-to-organism differences in $\mathrm{O}_{2}$ sensitivity. That from Klebsiella pneumoniae (Kelly, I969) is more $\mathrm{O}_{2}$-tolerant than those from Mycobacterium flavum (Biggins \& Postgate, I97I) and Clostridium pasteurianum (Kelly, I969) but is less $\mathrm{O}_{2}$-tolerant than the air-stable preparation from Azotobacter (see Kelly, 1969, and Yates \& Jones, 1974).

It has been suggested that the nitrogenase in intact Azotobacter is protected from $\mathrm{O}_{2}$ by two mechanisms: respiratory protection, where a low dissolved $\mathrm{O}_{2}$ tension is maintained by a controlled respiratory activity, and conformational protection, where the nitrogenase or its association with other proteins and membranes can undergo a controlled change so that the enzyme is both protected from $\mathrm{O}_{2}$ and inactive towards reducible substrates (Dalton \& Postgate, I969; Yates, 1970; Drozd \& Postgate, 1970; see also Yates \& Jones, I974). Other obligate aerobes such as $M$. flavum and Derxia gummosa are less $\mathrm{O}_{2}$-tolerant when fixing $\mathrm{N}_{2}$, probably because they do not possess such high respiratory rates as Azotobacter (see Yates \& Jones, 1974).

Although $\mathrm{O}_{2}$ probably represses nitrogenase synthesis in $K$. pneumoniae (St. John, Shah \& 
Brill, 1974), Klucas (1972) found that a species of Klebsiella synthesized nitrogenase when grown in a chemostat culture supplied with $\mathrm{O}_{2}$, provided that the medium contained a fixed $\mathrm{N}$ source (yeast extract) and the dissolved $\mathrm{O}_{2}$ tension was at $10 \mathrm{mmHg}$ or below. Klucas (1972) considered that nitrogenase activity did not depend on $\mathrm{O}_{2}$ because $\mathrm{C}_{2} \mathrm{H}_{2}$-reducing activity was irreversibly inhibited by low atmospheric $\mathrm{O}_{2}$ concentrations. He suggested that $\mathrm{O}_{2}$ tolerance occurred because of a high respiratory rate at low dissolved $\mathrm{O}_{2}$ tensions (Harrison \& Pirt, 1967; Harrison \& Loveless, 1971), although he did not measure respiration rates.

Klebsiella pneumoniae m5a I can grow and fix nitrogen on a solid medium in air (Hill, I975). It then shows a colony dimorphism resembling that of D. gummosa in air, but unlike D. gummosa a low level of fixed $\mathrm{N}$ is required. Colony dimorphism in both organisms probably arises because only where respiratory activity is sufficient to lower the local $\mathrm{O}_{2}$ tension, can $\mathrm{N}_{2}$ fixation and subsequent growth to the large colony type take place. The present work shows that, like D. gummosa (Hill \& Postgate, I969), K. pneumoniae can grow in a liquid $\mathrm{N}$-free medium supplied with $\mathrm{O}_{2}$ under $\mathrm{O}_{2}$ limitation. It also reports studies on the efficiency of $\mathrm{N}_{2}$ fixation and the nature of $\mathrm{O}_{2}$ inhibition of $\mathrm{C}_{2} \mathrm{H}_{2}$-reducing activity in K. pneumoniae grown with and without $\mathrm{O}_{2}$.

\section{METHODS}

Organism and culture. Klebsiella pneumoniae M5a I, a gift from Professor P. W. Wilson, was maintained at $20{ }^{\circ} \mathrm{C}$ in air on $2 \%$ nutrient agar slopes and subcultured monthly. Chemostat cultures (200 ml fitted with PVC tubing; Baker, 1968) were inoculated with about $5 \mathrm{ml}$ of an overnight culture grown on thioglycollate medium (Oxoid). The medium used for chemostat cultures contained (per litre): $12.06 \mathrm{~g} \mathrm{~K}_{2} \mathrm{HPO}_{4}, 3.4 \mathrm{~g} \mathrm{KH}_{2} \mathrm{PO}_{4}, 26 \mathrm{mg}$ $\mathrm{CaCl}_{2} .2 \mathrm{H}_{2} \mathrm{O}, 30 \mathrm{mg} \mathrm{MgSO}, 0.3 \mathrm{mg} \mathrm{MnSO}, 36 \mathrm{mg}$ ferric citrate, $7.6 \mathrm{mg} \mathrm{Na} \mathrm{MoO}_{4} .2 \mathrm{H}_{2} \mathrm{O}$, Io $\mu \mathrm{g} p$-aminobenzoic acid, $5 \mu \mathrm{g}$ biotin. The two vitamins are not in fact required by $K$. pneumoniae. Except where mentioned, growth was limited by glucose, present at from $\mathrm{I} 5$ to $30 \mathrm{~mm}$. When required, sufficient $\left(\mathrm{NH}_{4}\right)_{2} \mathrm{SO}_{4}$, at $3 \mathrm{mM}$, was included to repress nitrogenase synthesis. Phosphate and $\left(\mathrm{NH}_{4}\right)_{2} \mathrm{SO}_{4}$ solutions were sterilized independently and subsequently added aseptically. Organisms were grown at $30 \pm 0.5{ }^{\circ} \mathrm{C}$ under an atmosphere of either $\mathrm{N}_{2}$ or $\mathrm{N}_{2}+\mathrm{O}_{2}$ flowing at about $200 \mathrm{ml} \mathrm{min}^{-1}$. Medium reservoirs were maintained under an atmosphere of $\mathrm{N}_{2}$. The buffering capacity of the medium was sufficient to maintain the $\mathrm{pH}$ at $6 \cdot 7 \pm 0 \cdot \mathrm{I}$ for the $\mathrm{N}_{2}$-fixing cultures and at $6 \cdot 8 \pm 0 \cdot \mathrm{I}$ for $\mathrm{NH}_{4}{ }^{+}$-assimilating cultures. The criteria of glucose limitation were those of Hill, Drozd \& Postgate (1972). The oxygen electrode, a Johnson, Borkowski \& Engblom (1964) type (Western Biological, Sherborne, Dorset) fitted with a JB Laboratory Oxygen meter (Western Biological) and Griffin Nesco Recorder (Griffin \& George, Wembley, Middlesex), was calibrated with distilled water at $30{ }^{\circ} \mathrm{C}$ in equilibrium with various $\mathrm{O}_{2}+\mathrm{N}_{2}$ mixtures.

Assay for acetylene reduction. Nominally $25 \mathrm{ml}$ conical flasks $(35 \mathrm{ml})$ containing, when necessary, either $0.1 \mathrm{ml}$ glucose or $0.1 \mathrm{ml}$ glucose and $0.1 \mathrm{ml}$ chloramphenicol (as specified) were flushed with Ar and capped with Suba-Seal closures (William Freeman Ltd, Barnsley, Yorkshire). Volumes of $\mathrm{O}_{2}$, to give the required atmospheric $\mathrm{O}_{2}$ concentration, and of $\mathrm{C}_{2} \mathrm{H}_{2}(3.5 \mathrm{ml})$ were injected. Flasks were equilibrated at $30^{\circ} \mathrm{C}$ for $5 \mathrm{~min}$ and the excess pressure released. Two $\mathrm{ml}$ of culture sample collected under $\mathrm{N}_{2}$ were injected to start the assay, which was performed at $30{ }^{\circ} \mathrm{C}$ with a shaking rate of 84 strokes/min at an amplitude of $3.8 \mathrm{~cm}$. Assays were stopped after the required incubation by injecting $0 . \mathrm{I} \mathrm{ml}$ of $40 \%$ $(\mathrm{w} / \mathrm{v}) \mathrm{KOH}$ and then gas samples $(0.5 \mathrm{ml})$ were taken for analysis by gas chromatography. 
Alternatively, for experiments to determine the percentage recovery of $\mathrm{C}_{2} \mathrm{H}_{2}$-reducing activity after exposure to $\mathrm{O}_{2}$, gas samples $(0.5 \mathrm{ml})$ for gas chromatography were removed at intervals during incubation and replaced by $0.5 \mathrm{ml} \mathrm{Ar}$. Dilution of $\mathrm{C}_{2} \mathrm{H}_{4}$ was corrected for by measuring the concomitant dilution of $\mathrm{C}_{2} \mathrm{H}_{2}$. The amount of $\mathrm{C}_{2} \mathrm{H}_{4}$ produced was always $<4 \%$ of the $\mathrm{C}_{2} \mathrm{H}_{2}$ present. During these experiments samples were flushed with Ar for 5 min by inserting 2 needles, one of which was connected to the Ar supply; after removing the needles, $\mathrm{C}_{2} \mathrm{H}_{2}(3.5 \mathrm{ml})$ was injected and the excess pressure released. Gas samples $(0.5 \mathrm{ml})$ were injected into a Pye 104 gas chromatograph (Pye Unicam Ltd, Cambridge) fitted with a flame ionization detector and $45 \mathrm{~cm}$ column (I $\mathrm{mm}$ internal diameter) filled with either Porapak R or Porapak N (mesh 100 to 120) and maintained at $37{ }^{\circ} \mathrm{C}$ with $\mathrm{N}_{2}$ as carrier gas flowing at $7 \mathrm{ml} \mathrm{min}{ }^{-1}$. Ethylene peak heights were recorded and compared with standards.

Measurement of oxygen uptake rate. Chemostat culture sample $(2 \mathrm{ml})$ was introduced into an $\mathrm{O}_{2}$ electrode respirometer (Rank Bros, Bottisham, Cambridgeshire) and when required glucose $(0.1 \mathrm{ml})$ was added. The ambient $\mathrm{O}_{2}$ tension in the sample was raised to approximately $135 \mathrm{mmHg}$ by vigorous stirring and bubbling air through the sample. The respirometer lid was replaced and the $\mathrm{O}_{2}$ uptake measured (potential $\mathrm{O}_{2}$ uptake rate). When the $\mathrm{O}_{2}$ tension had dropped to near zero, the sample was again exposed to an ambient $\mathrm{O}_{2}$ tension of about $135 \mathrm{mmHg}$. This cycle was repeated, after which the subsequent $\mathrm{O}_{2}$ uptake rate was measured.

The rate of $\mathrm{O}_{2}$ uptake $\left(Q_{\mathrm{o}_{2}}\right)$ was calculated from:

$$
Q_{0_{2}}\left[\mathrm{nmol} \min ^{-1}(\mathrm{mg} \text { bacterial protein })^{-1}\right]=\frac{r}{2 p}
$$

where $p$ is the concentration of bacterial protein $/ \mathrm{ml}$ and $r$ the rate of depletion of $\mathrm{O}_{2}$ concentration from the $\mathrm{O}_{2}$-electrode cell at $30^{\circ} \mathrm{C}(\mathrm{nmol} \mathrm{min}-1)$, which had previously been calibrated with $2 \mathrm{ml}$ of air-saturated distilled $\mathrm{H}_{2} \mathrm{O}$ at $30{ }^{\circ} \mathrm{C}$. No correction was made for the influence of glucose, medium components and fermentation products on the solubility of $\mathrm{O}_{2}$.

Analyses. Dry weights were determined by washing organisms once with distilled $\mathrm{H}_{2} \mathrm{O}$ and drying to constant weight in preweighed dry beakers at $80^{\circ} \mathrm{C}$. Dried material was cooled in the presence of a desiccant and then weighed; two empty beakers were included throughout the drying and weighing procedure as a control for the condensation of moisture in the air on the glass surfaces during weighing. A minimum of two estimates in duplicate were made on each steady state. The standard deviation of the method was $5 \%$.

Measurements of extinction of culture, at $540 \mathrm{~nm}$ in an EEL Spectra against a water blank, were used only to monitor steady states.

Protein was estimated on washed organisms by the procedure of Lowry et al. (I95I). A minimum of two estimates in duplicate was made on each steady state. The standard deviation of the method was $5 \%$.

Total $\mathrm{N}$ of organisms was estimated on washed dried organisms, prepared as for dry weight, by a model I85 CHN analyser (Hewlett \& Packard, F and M Scientific Division, Avondale, Pennsylvania, U.S.A.). Initially the standard deviation of estimates of percentage $\mathrm{N}$ in four samples of dried organisms from a single steady state was less than $\mathrm{I} \%$, so subsequently, dried material from a single steady state was pooled and the $\mathrm{N}$ content estimated singly. Such estimates were more reproducible and not lower than measurements of the amount of $\mathrm{N}_{2}$ fixed made by micro-Kjeldahl digestion of samples of culture and of the medium, with analysis of $\mathrm{NH}_{3}$ (Chaney \& Marback, 1962) diffused from the digests. 
Glucose in cultures and media was estimated by a modification of the method using glucose oxidase and peroxidase described in Sigma's Technical Bulletin No. 5IO. The peroxidase-glucose oxidase enzyme was resuspended in $40 \mathrm{ml} \mathrm{H}_{2} \mathrm{O}$ instead of the recommended $100 \mathrm{ml}$. Incubation was carried out in the dark and $0.5 \mathrm{ml}$ of $0.5 \mathrm{M}-\mathrm{H}_{2} \mathrm{SO}_{4}$ was added to stabilize the light-sensitive coloured product (Møller \& Ottolenghi, I966) before $E_{400}$ was recorded. This procedure did not detect concentrations of glucose lower than $0.02 \mathrm{~mm}$. For estimates of the concentration of glucose in the medium, two separate dilutions differing by a factor of two were usually made, and each dilution was estimated in duplicate. The standard deviation of the method was $4 \%$. 'Clinistic' reagent strips (Ames Co., Slough, Buckinghamshire) were used for the rapid detection of glucose in cultures; this qualitative method did not detect concentrations of glucose below about $0.3 \mathrm{mM}$.

\section{RESULTS}

\section{The efficiency of nitrogen fixation in oxygen-limited chemostat cultures}

An anaerobic glucose-limited chemostat culture of $K$. pneumoniae was established in the $\mathrm{N}$-free medium at a dilution rate $(D)$ of about $\mathrm{O} \cdot \mathrm{I} \mathrm{h}^{-1}$. By introducing $\mathrm{O}_{2}$ into the gas supply gradually, in increments of about 0.004 atm after every two replacements of culture volume, steady states were obtained where the dissolved $\mathrm{O}_{2}$ tension was apparently zero and the residual glucose concentration was less than $0.02 \mathrm{~mm}$. These steady states were presumed to be $\mathrm{O}_{2}$-limited because (i) the dissolved $\mathrm{O}_{2}$ tension was apparently zero and (ii) increases in supplied $\mathrm{O}_{2}$ concentration, provided by increasing either the atmospheric $P_{\mathrm{O}_{2}}$ or the agitation rate, caused increases in the molar growth yield for glucose (Table I). An increase in molar growth yield caused by providing $\mathrm{O}_{2}$ suggests that some of the ATP required for growth was generated by oxidative phosphorylation.

In $\mathrm{O}_{2}$-limited chemostat cultures of a facultative anaerobe where ATP is generated by oxidative phosphorylation, the increase in molar growth yield for glucose should be influenced not only by the supplied atmospheric $P_{\mathrm{O}_{2}}$ and the agitation rate, but also by the dilution rate and the ratio of supplied concentrations of $\mathrm{O}_{2}$ and glucose (Pirt, I957). Although in the present work the dilution rate was maintained near $0 \cdot \mathrm{I} \mathrm{h}^{-1}$ the differences in supplied glucose concentration (Table I) may have influenced the magnitude of the molar growth yield.

The change from anaerobic glucose-limited growth to $\mathrm{O}_{2}$-limited growth did not influence the $\mathrm{N}$ content of the organisms. Therefore the efficiency of $\mathrm{N}_{2}$ fixation, like the molar growth yield, was also increased. The largest increase was $82 \%$ (Table I).

\section{Requirement for oxygen for acetylene reduction}

If $\mathrm{O}_{2}$-limited $\mathrm{N}_{2}$-fixing chemostat cultures of $K$. pneumoniae generate ATP by oxidative phosphorylation, $\mathrm{N}_{2}$ fixation by these populations might require $\mathrm{O}_{2}$. This was found to be the case in samples not supplemented with glucose, where $\mathrm{C}_{2} \mathrm{H}_{2}$-reducing activity required $\mathrm{O}_{2}$. The activity rose with increasing partial pressure to $0.02 \mathrm{~atm}$; higher partial pressures of $\mathrm{O}_{2}$ inhibited activity. Maximal activity was only $20 \%$ of that of an equivalent sample containing glucose (Fig. I). The anaerobic $\mathrm{C}_{2} \mathrm{H}_{2}$-reducing activity of samples from an $\mathrm{O}_{2}$-limited chemostat culture required the addition of glucose. When glucose was added, the only significant influence of atmospheric $\mathrm{O}_{2}$ was to inhibit the activity above about $0.02 \mathrm{~atm}$ (Fig. I).

Samples from an anaerobic glucose-limited $\mathrm{N}_{2}$-fixing chemostat culture behaved similarly. Under anaerobic conditions, $\mathrm{C}_{2} \mathrm{H}_{2}$-reducing activity required glucose, and was 
Table I. Increases of efficiency of $N_{2}$ fixation and molar growth yield for glucose ( $Y_{\text {glucose }}$ ) in $\mathrm{O}_{2}$-limited chemostat cultures

\begin{tabular}{|c|c|c|c|c|c|}
\hline$\underset{\left(\mathrm{h}^{-1}\right)}{D}$ & $\begin{array}{c}\text { Supplied } \\
\text { atmospheric } P_{\mathrm{O}_{2}} \\
\text { to culture }\end{array}$ & $\begin{array}{l}\text { Agitation rate } \\
\text { of culture } \\
\text { (rev./min) }\end{array}$ & $\begin{array}{l}\text { Supplied glucose } \\
\text { concentration } \\
(\mathrm{mm})\end{array}$ & $\begin{array}{c}Y_{\text {glucose }} \\
\left(\mathrm{g} \mathrm{mol}^{-1}\right)\end{array}$ & $\begin{array}{c}\text { Efficiency of } \\
\mathrm{N}_{2} \text { fixation } \\
\left(\mu \mathrm{g} \mathrm{N} \mathrm{N}_{2} \text { fixed } / \mathrm{mg}\right. \\
\text { glucose consumed })\end{array}$ \\
\hline 0.103 & 0 & $55^{8}$ & $3 I \cdot I$ & $I I \cdot I$ & 7.9 \\
\hline 0.104 & 0.005 & $55^{8}$ & $3 I \cdot I$ & $12 \cdot 4$ & 9.0 \\
\hline 0.106 & 0.035 & $55^{8}$ & $35 \cdot 3$ & $15 \cdot 6$ & 110 \\
\hline 0.110 & 0.019 & 595 & 23.9 & $18 \cdot 2$ & $13 \cdot 2$ \\
\hline 0.110 & 0.025 & 595 & $25 \cdot \mathrm{I}$ & $20 \cdot 4$ & 14.5 \\
\hline
\end{tabular}

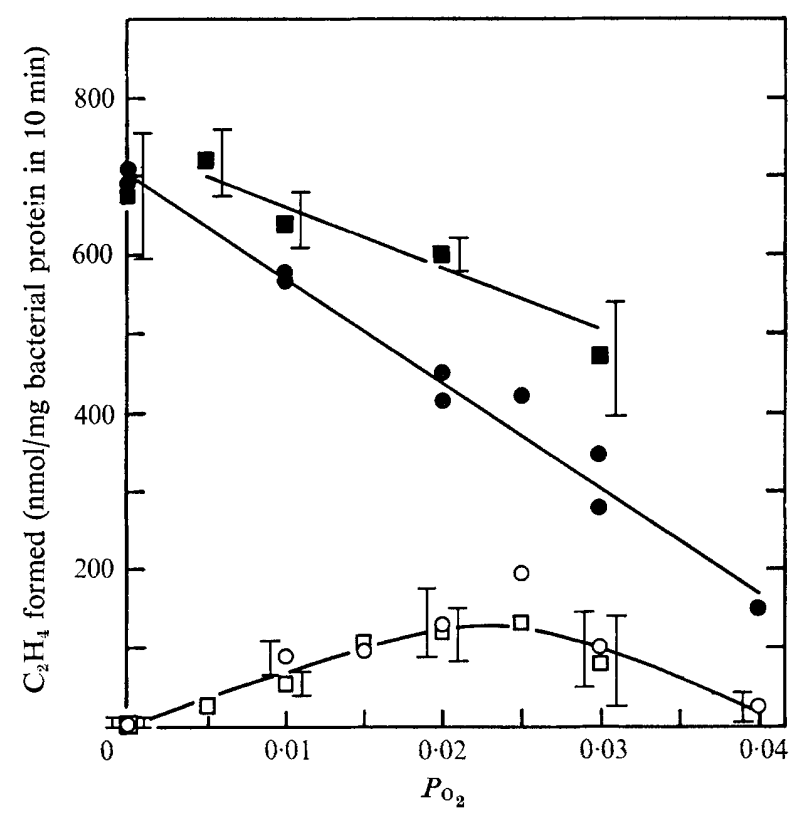

Fig. I. Influence of atmospheric $P_{\mathrm{O}_{2}}$ on $\mathrm{C}_{2} \mathrm{H}_{2}$-reducing activity in samples from an $\mathrm{O}_{2}$-limited $(\square, \boldsymbol{\square})$ and from anaerobic glucose limited $(O, 0)$ chemostat cultures. Samples were either supplemented with 60 mm-glucose (closed symbols) or unsupplemented (open symbols). The standard deviations of estimates are indicated by bars to the right and left of the symbols, for samples from $\mathrm{O}_{2}$-limited and from anaerobic glucose-limited chemostat cultures respectively. The population density of the $\mathrm{O}_{2}$-limited chemostat culture was $0.434 \mathrm{mg}$ dry weight $/ \mathrm{ml}$ and that of the anaerobic glucose chemostat cultures was either 0.343 or $0.392 \mathrm{mg} / \mathrm{ml}$; the $\mathrm{O}_{2}$-limited chemostat culture was supplied with atmospheric oxygen of $P_{\mathrm{O}_{2}}$ 0.019.

strongly inhibited by $\mathrm{O}_{2}$. However, in samples not supplemented with glucose, $\mathrm{C}_{2} \mathrm{H}_{2}$ reducing activity required $\mathrm{O}_{2}$. The maximum activity under 0.02 to $0.025 \mathrm{~atm} \mathrm{O}_{2}$ was about $40 \%$ of that in equivalent samples containing glucose (Fig. I).

\section{Tolerance to oxygen of acetylene reduction}

The tolerance of $\mathrm{C}_{2} \mathrm{H}_{2}$-reducing activity to low atmospheric $\mathrm{O}_{2}$ concentrations was slightly higher in glucose-supplemented samples from the $\mathrm{O}_{2}$-limited chemostat cultures than from the anaerobic glucose-limited chemostat cultures (Fig. I). Tolerance of $\mathrm{C}_{2} \mathrm{H}_{2}-$ reducing activity to 0.03 atm $\mathrm{O}_{2}$ in glucose-supplemented samples from various $\mathrm{O}_{2}$-limited 
Table 2. Tolerance of $\mathrm{C}_{2} \mathrm{H}_{2}$-reducing activity to 0.03 atm $\mathrm{O}_{2}$ in samples from various $\mathrm{O}_{2}$ limited and anaerobic glucose-limited chemostat cultures. For comparison, the population density and the increase in molar growth yield $\left(Y_{\text {glucose }}\right)$ are also shown

$\begin{array}{cc}\begin{array}{c}\text { Supplied atmospheric } \\ P_{\mathrm{O}_{2}} \text { to culture }\end{array} & \begin{array}{c}\text { Population density } \\ \text { (mg dry weight/ml) }\end{array} \\ 0 & 0.392 \\ 0 & 0.343 \\ 0 & 0.346 \\ 0.005 & 0.387 \\ 0.035 & 0.549 \\ 0.019 & 0.434 \\ 0.025 & 0.515\end{array}$

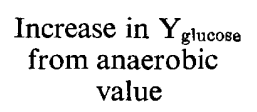

0
O
0
Marginal
$\mathrm{I} \cdot 4$
$\mathrm{I} \cdot 6$
$\mathrm{I} \cdot 8$

Tolerance of

$\mathrm{C}_{2} \mathrm{H}_{2}$-reducing activity to 0.03 atm $\mathrm{O}_{2}{ }^{*}$

$$
\begin{aligned}
& 4 \mathrm{I}(\mathrm{I}) \\
& 49(\mathrm{I}) \\
& 46 \pm \mathrm{I} 3(4) \\
& 4 \mathrm{I}, 43(2) \\
& 59(\mathrm{I}) \\
& 69 \pm 4(3) \\
& 88(\mathrm{I})
\end{aligned}
$$

* The tolerance of activity, defined as the percentage of $\mathrm{C}_{2} \mathrm{H}_{2}$-reducing activity found under 0.03 atm $\mathrm{O}_{2}$ compared with the activity found anaerobically, was estimated as $\mathrm{C}_{2} \mathrm{H}_{4}$ produced after Io min incubation in samples supplemented with glucose. The number in parenthesis indicates the numbers of estimates; where the number of estimates exceeds 2 , the standard deviation is given.

and anaerobic glucose-limited chemostat cultures are compared in Table 2. The tolerance was greater in samples from $\mathrm{O}_{2}$-limited than from anaerobic glucose-limited chemostat cultures, and can be correlated with the increase in molar growth yield from the anaerobic value rather than with the increase in population density (Table 2).

\section{Reversal of oxygen inhibition of acetylene-reducing activity}

Acetylene-reducing activity was completely inhibited by $0 \cdot 2 \mathrm{~atm} \mathrm{O}_{2}$ over samples removed from an anaerobic glucose-limited chemostat culture and supplemented with glucose and chloramphenicol. Activity was partially restored when the $\mathrm{O}_{2}$ had been removed by flushing the samples with Ar for $5 \mathrm{~min}$ (Fig. 2a). Maximum activity in samples exposed to $\mathrm{O}_{2}$ was preceded by a lag period and depended on the time of exposure to $\mathrm{O}_{2}$; the activity was $52 \%$ lower in samples exposed for $25 \mathrm{~min}$ than in samples exposed for $12 \mathrm{~min}$.

Complete inhibition of $\mathrm{C}_{2} \mathrm{H}_{2}$-reducing activity under 0.2 atm $\mathrm{O}_{2}$ also occurred in samples from $\mathrm{O}_{2}$-limited chemostat cultures, and this also was partially reversible. The percentage recovery of $\mathrm{C}_{2} \mathrm{H}_{2}$-reducing activity (see legend to Fig. 2) after $\mathrm{I} 2 \mathrm{~min}$ exposure to $0.2 \mathrm{~atm} \mathrm{O}_{2}$ was $43 \%$ in samples from the anaerobic glucose-limited chemostat culture, and 46 and $68 \%$ with $\mathrm{O}_{2}$-limited populations grown with 0.005 and 0.035 atm $\mathrm{O}_{2}$ respectively (Table 3). The lag period following exposure to $\mathrm{O}_{2}$ before $\mathrm{C}_{2} \mathrm{H}_{2}$-reducing activity became linear was $43 \%$ shorter in samples from the $\mathrm{O}_{2}$-limited chemostat cultures supplied with $0.035 \mathrm{~atm} \mathrm{O}_{2}$ (Table 3).

In the control samples which contained chloramphenicol and glucose, the rate $\mathrm{C}_{2} \mathrm{H}_{2}$ reduction in the first $\mathrm{I} 2 \mathrm{~min}$ was lower than the rate observed after the sample had been flushed with Ar for 5 min (Fig. 2a). Samples from the $\mathrm{O}_{2}$-limited chemostat cultures supplied with $0.035 \mathrm{~atm} \mathrm{O}_{2}$ showed no such increase (Fig. $2 b$; Table 3 ).

During the prolonged incubation following flushing with $\mathrm{Ar}$, anaerobic $\mathrm{C}_{2} \mathrm{H}_{2}$-reducing activity in samples from both $\mathrm{O}_{2}$-limited chemostat cultures declined slightly (Fig. $2 b$ ). Whether this decrease was due to specifically unstable nitrogenase, exhaustion of substrates for $\mathrm{C}_{2} \mathrm{H}_{2}$ reduction or appearance of an inhibitor was not established, but chloramphenicol was not involved since the same effect was observed in its absence. 

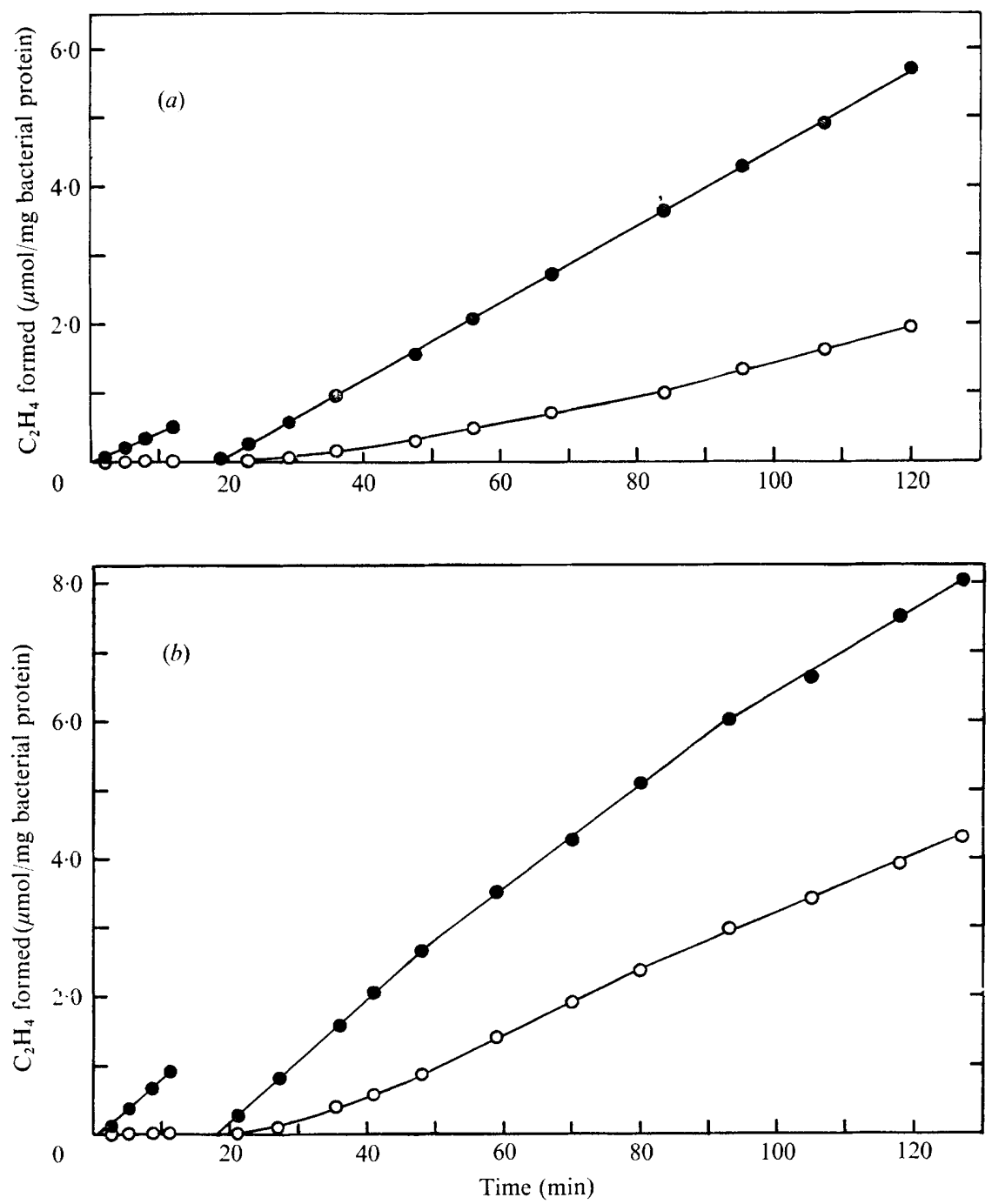

Fig. 2. Reversible inhibition of $\mathrm{C}_{2} \mathrm{H}_{2}$-reducing activity by $0.2 \mathrm{~atm} \mathrm{O}_{2}$ in samples from $(a)$ an anaerobic glucose-limited chemostat culture and $(b)$ an $\mathrm{O}_{2}$-limited chemostat culture supplied with $0.035 \mathrm{~atm} \mathrm{O}_{2}$. Samples, supplemented with $60 \mathrm{~mm}$-glucose and $0.31 \mathrm{Im}$-chloramphenicol were exposed for $12 \mathrm{~min}$ initially to either $0.2 \mathrm{~atm} \mathrm{O}_{2}+\mathrm{O} \cdot \mathrm{I}$ atm $\mathrm{C}_{2} \mathrm{H}_{2}$ in $\mathrm{Ar}(\mathrm{O})$ or $0 . \mathrm{I}$ atm $\mathrm{C}_{2} \mathrm{H}_{2}$ in $\operatorname{Ar}(\bullet)$. Both samples were then flushed with $\mathrm{Ar}$ for $5 \mathrm{~min}$, when $\mathrm{C}_{2} \mathrm{H}_{2}$ to $0 . \mathrm{I} \mathrm{atm}$ was injected. Gas samples were removed at intervals for analyses. The percentage recovery of $\mathrm{C}_{2} \mathrm{H}_{2}$-reducing activity in the $\mathrm{O}_{2}$-treated sample (see Table 3 ) was estimated by comparing the rate of subsequent linear anaerobic $\mathrm{C}_{2} \mathrm{H}_{2}$ reduction in the $\mathrm{O}_{2}$-treated sample with the final rate of $\mathrm{C}_{2} \mathrm{H}_{2}$ reduction in the control sample.

\section{Potential oxygen uptake rates}

A higher potential for $\mathrm{O}_{2}$ removal might account for the greater tolerance of $\mathrm{C}_{2} \mathrm{H}_{2}$ reducing activity towards $\mathrm{O}_{2}$ in samples from $\mathrm{O}_{2}$-limited chemostat cultures compared with those from anaerobic glucose-limited ones. Therefore the potential $\mathrm{O}_{2}$-uptake rates in samples from $\mathrm{O}_{2}$-limited $\mathrm{N}_{2}$-fixing chemostat cultures, an anaerobic glucose-limited $\mathrm{N}_{2}$ fixing chemostat culture and an anaerobic glucose-limited $\mathrm{NH}_{4}{ }^{+}$-assimilating chemostat 
Table 3. Comparison of recovery of anaerobic $\mathrm{C}_{2} \mathrm{H}_{2}$-reducing activity after exposure to $0.2 \mathrm{~atm} \mathrm{O}_{2}$ for $12 \mathrm{~min}$ in glucose- and chloramphenicol-supplemented samples from $\mathrm{O}_{2}$-limited and anaerobic glucose-limited chemostat cultures

Each estimate was made in duplicate, therefore the range of estimates is indicated.

\begin{tabular}{|c|c|c|c|c|}
\hline \multirow[b]{2}{*}{$\begin{array}{c}\text { Supplied } \\
\text { atmospheric } \\
P_{\mathrm{O}_{2}} \text { to culture }\end{array}$} & \multicolumn{3}{|c|}{ Recovery of $\mathrm{C}_{2} \mathrm{H}_{2}$-reducing activity } & \multirow[b]{2}{*}{$\begin{array}{c}\text { Increase in } \\
\mathrm{C}_{2} \mathrm{H}_{2} \text {-reducing } \\
\text { activity in } \\
\text { control sample } \dagger \\
(\%)\end{array}$} \\
\hline & $\begin{array}{l}\text { Population } \\
\text { density }(\mathrm{mg} \text { dry } \\
\text { weight } / \mathrm{ml})\end{array}$ & $\begin{array}{l}\text { Recovery of } \\
\text { activity after } \\
\mathrm{O}_{2} \text { treatment* } \\
(\%)\end{array}$ & $\begin{array}{c}\text { Lag after } \mathrm{O}_{2} \\
\text { treatment before } \\
\text { linear } \mathrm{C}_{2} \mathrm{H}_{2} \\
\text { reduction }(\mathrm{min})\end{array}$ & \\
\hline 0 & 0.346 & 43 & 64 & $25 \pm 6$ \\
\hline 0.005 & 0.387 & & $5^{8} \pm 7$ & $17 \pm 4$ \\
\hline 0.035 & 0.549 & $68 \pm 6$ & $35 \pm 2$ & 0 \\
\hline
\end{tabular}

* The estimate of percentage recovery of $\mathrm{C}_{2} \mathrm{H}_{2}$-reducing activity after $\mathrm{O}_{2}$ treatment is defined in the legend to Fig. 2.

$\dagger$ See text.

Table 4. Comparison of potential $O_{2}$-uptake rates $\left(Q_{\mathrm{o}_{2}}\right)$ and apparent sensitivity of $\mathrm{O}_{2}$ uptake to $\mathrm{O}_{2}$ in samples from $\mathrm{O}_{2}$-limited and from anaerobic glucose-limited chemostat cultures

\begin{tabular}{|c|c|c|c|c|c|c|}
\hline \multirow[b]{2}{*}{$\begin{array}{l}\text { N source } \\
\text { for } \\
\text { culture }\end{array}$} & \multirow[b]{2}{*}{$\begin{array}{c}D \\
\left(\mathrm{~h}^{-1}\right)\end{array}$} & \multirow{2}{*}{$\begin{array}{c}\text { Supplied } \\
\text { atmospheric } \\
P_{\mathrm{O}_{2}} \text { to } \\
\text { culture }\end{array}$} & \multirow{2}{*}{$\begin{array}{c}\text { Population } \\
\text { density } \\
\text { (mg dry } \\
\text { weight } / \mathrm{ml} \text { ) }\end{array}$} & \multicolumn{2}{|c|}{$\begin{array}{c}\text { Potential } Q_{\mathrm{O}_{2}}{ }^{*} \\
{\left[\mathrm{nmol}(\mathrm{mg} \text { bacterial protein })^{-1} \mathrm{~min}^{-1}\right]}\end{array}$} & \multirow[b]{2}{*}{$\begin{array}{l}\text { Sensitivity of } \\
\mathrm{O}_{2} \text { uptake* } \dagger\end{array}$} \\
\hline & & & & $\begin{array}{l}\text { Without added } \\
\text { glucose }\end{array}$ & $\begin{array}{c}\text { With added } \\
\text { glucose }(60 \mathrm{~mm})\end{array}$ & \\
\hline \multirow[t]{3}{*}{$\mathrm{N}_{2}$} & 0.103 & 0 & 0.346 & $188 \pm$ & 299 & $64,57(2)$ \\
\hline & 0.104 & 0.005 & 0.387 & $198 \pm 22(3)$ & $288 \pm 12(4)$ & $24 \pm 5(3)$ \\
\hline & 0.106 & 0.035 & 0.549 & $256264(2)$ & $305320(2)$ & II (I) \\
\hline $\mathrm{NH}_{4}{ }^{+}$ & 0.102 & 0 & 0.429 & $90 \pm 22(3)$ & $23 I \pm 28$ & $10 \pm 6(3)$ \\
\hline
\end{tabular}

* The numbers in parenthesis indicate the number of estimates; where the number of estimates exceeds two the standard deviation is given.

$\uparrow$ The apparent sensitivity of $\mathrm{O}_{2}$ uptake to $\mathrm{O}_{2}$ is defined as the percentage loss of $\mathrm{O}_{2}$ uptake rate in a sample containing glucose after three consecutive exposures to an ambient $\mathrm{O}_{2}$ tension of approximately I $35 \mathrm{mmHg}$ (see Methods).

culture were compared. In all samples the potential $\mathrm{O}_{2}$-uptake rate was increased by adding glucose. When glucose was added the potential $\mathrm{O}_{2}$-uptake rates were not significantly different in samples from these chemostat cultures (Table 4). After a second and third exposure to the same dissolved oxygen tension in the respirometer, the subsequent $\mathrm{O}_{2}$ uptake rate in samples was lower. This apparent sensitivity of the $\mathrm{O}_{2}$-uptake mechanism was more marked in samples from the anaerobic glucose-limited $\mathrm{N}_{2}$-fixing chemostat culture than in samples from the $\mathrm{O}_{2}$-limited $\mathrm{N}_{2}$-fixing chemostat cultures, and was probably in part associated with the $\mathrm{N}_{2}$-fixing process because samples from the anaerobic glucoselimited $\mathrm{NH}_{4}{ }^{+}$-assimilating chemostat cultures did not show the same sensitivity (Table 4 ).

\section{DISCUSSION}

The increase in efficiency of nitrogen fixation. The increases in molar growth yield and efficiency of $\mathrm{N}_{2}$ fixation when $\mathrm{O}_{2}$ was supplied to the chemostat culture suggests that a proportion of the ATP required for $\mathrm{N}_{2}$ fixation and growth was generated by oxidative 
phosphorylation. On the other hand, these increases may reflect a lowering of the amount of ATP required for $\mathrm{N}_{2}$ fixation. However, estimates of the apparent ATP requirement for $\mathrm{N}_{2}$ fixation in $\mathrm{O}_{2}$-limited chemostat cultures of $K$. pneumoniae (Hill, unpublished) were not lower than those in anaerobic glucose-limited chemostat cultures (Hill, Drozd \& Postgate, 1972). Additional circumstantial evidence in the present work suggests that ATP produced from oxidative phosphorylation could be used for $\mathrm{N}_{2}$ fixation in the $\mathrm{O}_{2}$-limited chemostat culture, since $\mathrm{C}_{2} \mathrm{H}_{2}$-reducing activity in samples from this chemostat culture required $\mathrm{O}_{2}$ when glucose was not provided. This phenomenon was also observed in samples from an anaerobic glucose-limited chemostat culture, which implies that the enzymic apparatus for oxidative phosphorylation is present during anaerobic growth. Other facultative anaerobes growing anaerobically are known to contain some of the components of oxidative phosphorylation (see Wimpenny, I969). Klebsiella aerogenes [NCIB80I7; this strain has been shown to fix $\mathrm{N}_{2}$ (Dixon, I972)] grown anaerobically in glucose-limited chemostat culture supplied with $\mathrm{NH}_{4}{ }^{+}$contained cytochromes $a_{1}, a_{2}$ and $b_{1}$ (Harrison, 1972). Thus, contrary to the conclusions of Klucas (1972), it seems likely that ATP produced from oxidative phosphorylation can be used for $\mathrm{N}_{2}$ fixation in K. pneumoniae.

Protection of nitrogenase from oxygen. Klucas (1972) found that the inhibition of $\mathrm{C}_{2} \mathrm{H}_{2}-$ reducing activity under $\mathrm{O} \cdot \mathrm{I}$ atm $\mathrm{O}_{2}$ in a species of Klebsiella was irreversible, although the length of exposure to $\mathrm{O}_{2}$ and the time of incubation under anaerobic conditions following $\mathrm{O}_{2}$ treatment were not specified.

In samples from anaerobic glucose-limited and $\mathrm{O}_{2}$-limited chemostat cultures of $K$. pneumoniae a proportion of the $\mathrm{C}_{2} \mathrm{H}_{2}$-reducing activity, completely inhibited under $0.2 \mathrm{~atm}$ $\mathrm{O}_{2}$, returned when $\mathrm{O}_{2}$ was removed. This return of activity was not due to protein synthesis because chloramphenicol was present and is known to inhibit protein synthesis in this strain of K. pneumoniae (Tubb \& Postgate, 1973). However, in the control samples, removal of $\mathrm{C}_{2} \mathrm{H}_{2}$ seemed to activate primarily inactive nitrogenase and comparable activation may have happened in the $\mathrm{O}_{2}$-treated samples, although the magnitude of this effect in the control samples indicates that it could only account for a part of the recovery. When $\mathrm{O}_{2}$ treatment of samples from the anaerobic chemostat culture was lengthened from 12 to $25 \mathrm{~min}$, the recovery of $\mathrm{C}_{2} \mathrm{H}_{2}$-reducing activity was less. This indicates that the irreversible damage caused by $\mathrm{O}_{2}$ increased with time. Consequently, recovery of activity was probably due to the remaining undamaged nitrogenase, and was not caused by activation of inactive nitrogenase. Thus a proportion of the $\mathrm{C}_{2} \mathrm{H}_{2}$-reducing activity, completely inhibited by $\mathrm{O}_{2}$, was reversible.

It follows that nitrogenase in $K$. pneumoniae may be protected from $\mathrm{O}_{2}$ by some process analogous to the conformational change proposed to explain the 'switch on-off' phenomenon in Azotobacter (see Yates \& Jones, 1974). Hence this phenomenon, whereby $\mathrm{O}_{2}$ damage to nitrogenase is prevented and $\mathrm{C}_{2} \mathrm{H}_{2}$ (and by implication $\mathrm{N}_{2}$ ) reduction does not occur, is not a specific characteristic of obligate aerobic $\mathrm{N}_{2}$ fixers.

An increase in $\mathrm{C}_{2} \mathrm{H}_{2}$-reducing activity in the absence of protein synthesis de novo was observed in an anaerobic $\mathrm{N}_{2}$-fixing $\mathrm{SO}_{4}{ }^{2-}$-limited chemostat culture of $K$. pneumoniae by Tubb \& Postgate (1973), who suggested that activation of inactive nitrogenase might account for the increase in activity. Since I did not observe any increase in $\mathrm{C}_{2} \mathrm{H}_{2}$-reducing activity in samples from anaerobic glucose-limited chemostat cultures with chloramphenicol when $\mathrm{C}_{2} \mathrm{H}_{2}$ was present, it is likely that $\mathrm{C}_{2} \mathrm{H}_{2}$ inhibits the increase in nitrogenase activity; the inhibition was temporarily lifted when samples were flushed with Ar for 5 min.

Samples from $\mathrm{O}_{2}$-limited chemostat cultures, when compared with those from anaerobic glucose-limited chemostat cultures, showed (i) a greater tolerance of $\mathrm{C}_{2} \mathrm{H}_{2}$-reducing activity 
to $\mathrm{O}_{2}$ (Fig. I ; Table 2) and (ii) a greater percentage and faster recovery of $\mathrm{C}_{2} \mathrm{H}_{2}$-reducing activity following complete inhibition of activity by $\mathrm{O}_{2}$ (Table 3). Although the initial potential $\mathrm{O}_{2}$-uptake rates were similar in samples from $\mathrm{O}_{2}$-limited and from anaerobic glucose-limited chemostat cultures, samples from the former chemostat cultures showed a greater capacity for continued $\mathrm{O}_{2}$ uptake. Oxygen-limited chemostat cultures also had a greater population density and a higher molar growth yield than the anaerobic glucoselimited chemostat cultures. The higher population density, together with a greater capacity for continued $\mathrm{O}_{2}$ uptake, would increase the rate of $\mathrm{O}_{2}$ removal and thus prevent $\mathrm{O}_{2}$ from reaching the $\mathrm{O}_{2}$-sensitive sites of the $\mathrm{C}_{2} \mathrm{H}_{2}$-reducing process. On the other hand, the degree of recovery of $\mathrm{C}_{2} \mathrm{H}_{2}$-reducing activity after complete inhibition by $\mathrm{O}_{2}$ may reflect the supply of a limiting substrate rather than the level of nitrogenase present.

Oxygen uptake, supported by the endogenous source of reducing power in samples from anaerobic glucose-limited and from $\mathrm{O}_{2}$-limited chemostat cultures, could account for the ability of these unsupplemented samples to reduce $\mathrm{C}_{2} \mathrm{H}_{2}$ in low atmospheric $\mathrm{O}_{2}$ concentrations. Under these conditions the endogenous source of reducing power would probably supply electrons for $\mathrm{O}_{2}$ uptake, concomitant ATP production and for $\mathrm{C}_{2} \mathrm{H}_{2}$ reduction.

Thus nitrogenase in Klebsiella is probably protected from $\mathrm{O}_{2}$ by both respiratory protection and conformational protection as in Azobacter. The potential $\mathrm{O}_{2}$-uptake rates in samples from anaerobic glucose-limited and from $\mathrm{O}_{2}$-limited chemostat cultures of $K$. pneumoniae were similar to those found by Harrison \& Loveless (I97I) in samples from anaerobic glucose-limited and from $\mathrm{O}_{2}$-limited chemostat cultures of Klebsiella aerogenes (NCIB80I7) supplied with $\mathrm{NH}_{4}{ }^{+}$. The potential $\mathrm{O}_{2}$-uptake rates of $K$. aerogenes (NCIB80I7) in samples from glucose-limited (Harrison \& Loveless, I97I) and from $\mathrm{NH}_{4}{ }^{+}$-limited (Harrison \& Pirt, I967) chemostat cultures increased when the $\mathrm{O}_{2}$ supply to the culture was lowered. In the latter culture at zero or low $\mathrm{O}_{2}$ tensions the organisms were probably fixing $\mathrm{N}_{2}$. On the other hand, respiratory activity in Azotobacter increases in response to an increase in dissolved $\mathrm{O}_{2}$ tension (Yates \& Jones, 1974). Thus this difference in response of respiratory activity to dissolved $\mathrm{O}_{2}$ tension between Azotobacter and Klebsiella may account in part for the occurrence of $\mathrm{N}_{2}$ fixation in Klebsiella only during anaerobic growth or under or near $\mathrm{O}_{2}$ limitation. Although the ATP produced from oxidative phosphorylation in $\mathrm{O}_{2}-$ limited $\mathrm{N}_{2}$-fixing chemostat cultures of $K$. pneumoniae can probably be used for $\mathrm{N}_{2}$ fixation and growth, reducing power for nitrogenase activity may be available only from anaerobic processes. Pyruvate or formate can support $\mathrm{C}_{2} \mathrm{H}_{2}$ reduction in crude extracts of $K$. pneumoniae (Yoch, 1974). The formate dehydrogenase associated with evolution of $\mathrm{H}_{2}$ from formate in the coli-aerogenes group is $\mathrm{O}_{2}$ sensitive (Peck \& Gest, I957; Ruiz-Herrera \& Alvarez, 1972). Therefore the supply of reducing power for nitrogenase activity in intact $K$. pneumoniae may operate only at zero or very low $\mathrm{O}_{2}$ tensions and, like nitrogenase (St. John et al., 1974), may be repressed by $\mathrm{O}_{2}$.

I thank Professor J. R. Postgate, Dr R. R. Eady and Dr M. G. Yates for useful discussion and for reviewing the manuscript, and $\mathrm{Mr}$ E. Kavanagh for technical assistance.

\section{REFERENCES}

BAKER, K. (1968). Low cost continuous culture apparatus. Laboratory Practice 17, 817-824.

Biggins, D. R. \& Postgate, J. R. (197I). Nitrogen fixation by extracts of Mycobacterium flavum 301, use of natural electron donors and oxygen sensitivity of cell-free preparations. European Journal of Biochemistry 19, 408-415.

Chaney, A. L. \& Marbach, E. P. (I962). Modified reagents for determination of urea and ammonia. Clinical Chemistry 8, 130-132. 
Dalton, H. \& Postgate, J. R. (1969). Effect of oxygen on growth of Azotobacter chroococcum in batch and continuous culture. Journal of General Microbiology 56, 307-319.

Dixon, R. A. (1972). Genetics of nitrogen fixation in coliform bacteria. D.Phil. thesis, University of Sussex.

DrozD, J. \& Postgate, J. R. (1970). Effects of oxygen on acetylene reduction, cytochrome content and respiratory activity of Azotobacter chroococcum. Journal of General Microbiology 63, 63-73.

Eady, R. R. \& Postgate, J. R. (1974). Nitrogenase. Nature, London 249, 805-810.

Harrison, D. E. F. (1972). A study of the effect of growth conditions on chemostat-grown Klebsiella aerogenes and kinetic changes of a $500 \mathrm{~nm}$ absorption band. Biochimica et biophysica acta 275, 83-92.

HARRISON, D. E. F. \& Loveless, J. E. (I97I). The effect of growth conditions on respiratory activity and growth efficiency in facultative anaerobes grown in chemostat culture. Journal of General Microbiology $68,35-43$.

Harrison, D. E. F. \& PIRT, S. J. (1967). The influence of dissolved oxygen concentration on the respiration and glucose metabolism of Klebsiella aerogenes during growth. Journal of General Microbiology 46, I 93-2II.

Hill, S. (1975). Acetylene reduction by Klebsiella pneumoniae in air related to colony dimorphism on low fixed nitrogen. Journal of General Microbiology 9r, 207-209.

Hill, S., Drozd, J. W. \& Postgate, J. R. (1972). Environmental effects on the growth of nitrogen-fixing bacteria. Journal of Applied Chemistry and Biotechnology 22, 54I-558.

Hill, S. \& Postgate, J. R. (1969). Failure of putative nitrogen-fixing bacteria to fix nitrogen. Journal of General Microbiology 58, 277-285.

Johnson, M. J., Borkowski, J. \& EngBlom, C. (I964). Steam sterilizable probes for dissolved oxygen measurement. Biotechnology and Bioengineering 6, 457-468.

Kelly, M. (1969). Comparisons and cross-reactions of nitrogenase from Klebsiella pneumoniae, Azotobacter chroococcum and Bacillus polymyxa. Biochimica et biophysica acta 19r, 527-540.

KLUCAS, R. (1972). Nitrogen fixation by Klebsiella grown in the presence of oxygen. Canadian Journal of Microbiology 18, I845-1850.

Lowry, O. H., Rosebrough, N. J., Farr, A. L. \& Randall, R. J. (I95I). Protein measurement with the Folin phenol reagent. Journal of Biological Chemistry 193, 265-275.

Möller, M. K. \& Ottolenghi, P. (1966). The oxidation of o-dianisidine by $\mathrm{H}_{2} \mathrm{O}_{2}$ and peroxidase at neutral $\mathrm{pH}$. Comptes rendus des travaux du Laboratoire Carlsberg 35, 369-389.

PeCK, H. D., JR. \& Gest, H. (I957). Formic dehydrogenase and hydrogenylase enzyme complex in coliaerogenes bacteria. Journal of Bacteriology 73, 706-72I.

PIRT, S. J. (1957). The oxygen requirement of growing cultures of an Aerobacter species determined by means of the continuous culture technique. Journal of General Microbiology 16, 59-75.

Ruiz-Herrera, J. \& Alvarez, A. (1972). A physiological study of formate dehydrogenase, formate oxidase and hydrogenylase from Escherichia coli K-I2. Antonie van Leeuwenhoek 38, 479-49I.

ST. John, R. T., ShAH, V. K. \& BriLl, W. J. (1974). Regulation of nitrogenase synthesis by oxygen in Klebsiella pneumoniae. Journal of Bacteriology 119, 266-269.

Tubb, R. S. \& Postgate, J. R. (I973). Control of nitrogenase synthesis in Klebsiella pneumoniae. Journal of General Microbiology 79, I03-I I7.

WIMPENNY, J. W. T. (1969). Oxygen and carbon dioxide as regulators of microbial growth and metabolism. Symposium of the Society for General Microbiology 19, 16I-197.

YATES, M. G. (1970). Control of respiration and nitrogen fixation by oxygen and adenine nucleotides in $\mathrm{N}_{2}$-grown Azotobacter chroococcum. Journal of General Microbiology 60, 393-401.

YATES, M. G. \& Jones, C. W. (1974). Respiration and nitrogen fixation in Azotobacter. Advances in Microbial Physiology II, 97-I 35.

YocH, D. C. (1974). Electron transport carriers involved in nitrogen fixation by the coliform Klebsiella pneumoniae. Journal of General Microbiology 83, 153-164. 